\title{
Adsorption of Amyloglucosidase from Aspergillus niger NRRL 3122 Using Ion Exchange Resin
}

\author{
Ana Paula Manera ${ }^{1}$, Eliana Setsuko Kamimura ${ }^{2}$, Luciana Machado Brites ${ }^{1}$ and Susana \\ Juliano Kalil $^{\text {** }}$ \\ ${ }^{1}$ Departamento de Química; Universidade Federal do Rio Grande; Rua Engenheiro Alfredo Huch, 475; C.P.: 474; \\ dqmsjk@furg.br; 96201-900; Rio Grande - RS - Brasil. ${ }^{2}$ Departamento de Engenharia de Alimentos; Faculdade de \\ Zootecnia e Engenharia de Alimentos; Universidade de São Paulo; Av. Duque de Caxias Norte, 225; C.P.: 23; \\ 13635-900; Pirassununga - SP - Brasil
}

\begin{abstract}
Amyloglucosidase enzyme was produced by Aspergillus niger NRRL 3122 from solid-state fermentation, using deffated rice bran as substrate. The effects of process parameters ( $\mathrm{pH}$, temperature) in the equilibrium partition coefficient for the system amyloglucosidase - resin DEAE-cellulose were investigated, aiming at obtaining the optimum conditions for a subsequent purification process. The highest partition coefficients were obtained using $0.025 \mathrm{M}$ Tris- $\mathrm{HCl}$ buffer, $\mathrm{pH} 8.0$ and $25^{\circ} \mathrm{C}$. The conditions that supplied the highest partition coefficient were specified, the isotherm that better described the amyloglucosidase process of adsorption obtained. It was observed that the adsorption could be well described by Langmuir equation and the values of $Q_{m}$ and $K_{d}$ estimated at $133.0 U$ $m L^{-1}$ and $15.4 \mathrm{U} \mathrm{mL}^{-1}$, respectively. From the adjustment of the kinetic curves using the fourth-order Runge-Kutta algorithm, the adsorption $\left(k_{1}\right)$ and desorption $\left(k_{2}\right)$ constants were obtained through optimization by the least square procedure, and the values calculated were $2.4 \times 10^{-3} \mathrm{~mL} \mathrm{U}^{-1} \mathrm{~min}^{-1}$ for $k_{1}$ and $0.037 \mathrm{~min}^{-1}$ for $k_{2}$.
\end{abstract}

Key words: amyloglucosidase, adsorption isotherm, kinetics adsorption, ion exchange resin, purification

\section{INTRODUCTION}

Glucoamylase or amyloglucosidase (E.C. 3.2.1.3) is an exo-splitting enzyme, which removes the successive glucose units from the nonreducing ends of the substrate chain (Whitaker, 1994). This enzyme is widely used in food and fermentation industries in the process of starch saccharification. Amyloglucosidase from Aspergillus niger is one of the most economically important industrial enzymes. At present, glucose is mainly produced by the enzymatic hydrolysis of starch using $\alpha$ - amylase and amyloglucosidase since it is economical and efficient, and a pure product is obtained in the final stages of the process (Rani et al., 2000).

In recent years, solid-state fermentation has shown much promise in the development of several bioprocesses and products (Pandey et al., 2000). Traditionally, amyloglucosidase has been produced by the submerged fermentation and used in a one-way process in solution. Nowadays, the solid-state fermentation process has been

*Author for correspondence 
increasingly applied for the production of this enzyme (Ellaiah et al., 2002).

When amyloglucosidases are produced, they are often contaminated by a number of other enzymes that are active on starches. Therefore, enzyme preparations with a higher glucoamylase activity are in demand in the food industry (Harsa and Furusaki, 1994).

Isolation and purification of amyloglucosidase have recently been reported (Gouveia and Kilikian, 2000; Marlida et al., 2000; Chen et al., 2005). Purification procedures are usually based on series of techniques such as affinity chromatography, size-exclusion chromatography, ion exchange chromatography and bioaffinity extraction.

Ion exchange chromatography is an established technique used in the separation of charged molecules across a range of applications and industries. Chemically, ion exchange involves the exchange of solutes of like charge from a solid support bearing the opposite charge (adsorbent).

Ion exchange is a widely used technique in bioseparations since peptides, proteins, nucleic acids and related biopolymers have ionisable chemical moieties, which render them susceptible to charge enhancement or reversion as a function of $\mathrm{pH}$ (Levison, 2003). Therefore, there is a need to explore the adsorption-desorption characteristics of glucoamylases on ion exchange to provide data for an alternative separation process design. The selection of optimum process parameters (e.g. $\mathrm{pH}$, temperature) for purification is important not only for the maximum adsorption conditions but also for removing other contaminating enzymes.

The aim of this work was to study the effect of the key process parameters $(\mathrm{pH}$, temperature) on the phase equilibria of amyloglucosidase - resin DEAE-cellulose. The adsorption isotherms of glucoamylase enzyme as well as the adsorption kinetics were investigated.

\section{MATERIAL AND METHODS}

\section{Microorganism}

Aspergillus niger NRRL 3122 was maintained at $4^{\circ} \mathrm{C}$ in a test tube containing potato-dextrose agar. The subculturing was realized on potato-dextrose agar incubated at $30^{\circ} \mathrm{C}$ for $72 \mathrm{~h}$ until complete sporulation.

\section{Extracellular amyloglucosidase production}

The solid substrate used was the defatted thermally stabilized rice bran. Mineral salts and urea were added as nutrients and rice straw as medium support. The medium was adjusted to $50 \%$ moisture. The starch gelatinization and mixture sterilization were carried out at $121^{\circ} \mathrm{C}$ for $15 \mathrm{~min}$. Fermentation was carried out by taking $100 \mathrm{~g}$ of the wet substrate in a $500 \mathrm{~mL}$ Erlenmeyer flask and inoculating it with $4 \times 10^{6}$ spores $\mathrm{g}^{-1}$ of medium. The flask was incubated at $30^{\circ} \mathrm{C}$ for $72 \mathrm{~h}$ (Costa et al., 1998).

\section{Enzyme extraction}

Water was added in Erlenmeyer flasks with the fermented samples (in a 1:10 ratio) and the extraction was done in a shaker at $200 \mathrm{rpm}$ for $3 \mathrm{~h}$ at $25^{\circ} \mathrm{C}$ (Ghildyal et al., 1991). The sample was then filtered and the extract obtained was used for the adsorption studies.

\section{Enzyme activity assay}

Samples were collected and analysed as soon as possible. Amyloglucosidase activity was determined by the amount of glucose produced by the action of the enzyme. A $0.5 \mathrm{~mL}$ of the sample previously diluted was added to $12.5 \mathrm{~mL}$ of starch solution $(4 \%, \mathrm{w} / \mathrm{v}) \mathrm{pH} 4.2$ at $60^{\circ} \mathrm{C}$ over a period of 60 min (Gouveia and Kilikian, 2000). The amount of glucose produced after 60 min was quantified by the 3,5-dinitrosalicilic acid method (Miller, 1959). One unit of enzyme activity was defined as the amount of enzyme that liberated $1 \mu \mathrm{mol}$ reducing sugar (as glucose) per min under the standard assay conditions.

\section{Adsorvent resin}

In all the assays, the anion exchange resin DEAEcellulose $\left(\right.$ SIGMA $\left.^{\circledR}\right)$ was used, with density $1.13 \mathrm{~g}$ $\mathrm{mL}^{-1}$, specific superficial area $0.056 \mathrm{~m}^{2} \mathrm{~g}^{-1}$, mean diameter $95 \mu \mathrm{m}$, capacity $1 \mathrm{meq}^{-1}$. The resin consisted of an inert, cellulose matrix that carried diethylaminoethyl functional groups. This was a weak anion exchange resin. At the beginning of each experiment, the resin was washed into a buffer solution in desired $\mathrm{pH}$ until reaching the equilibrium. For stage of resin regeneration, it was washed with $0.5 \mathrm{M} \mathrm{NaOH}$ and let it for $12 \mathrm{~h}$ at room temperature. After this stage, the resin was washed in the following three step: first with desmineralized water, second with $0.1 \mathrm{M}$ Tris- $\mathrm{HCl}$ buffer, $\mathrm{pH} 7.5$, and third with $0.025 \mathrm{M}$ Tris- $\mathrm{HCl}$, in desired $\mathrm{pH}$ until reaching the equilibrium. 


\section{Effect of $\mathbf{p H}$ on partitioning}

The effect of $\mathrm{pH}$ on amyloglucosidase partition was studied using systems at different $\mathrm{pH}$ (6.5; $7.5 ; 8.0 ; 8.5$ and 9.0). Resins were equilibrated in appropriate $0.025 \mathrm{M}$ buffer solutions, amyloglucosidase was added in the appropriate $\mathrm{pH}$. Adsorption experiments were carried out in a shaker for $200 \mathrm{~min}$. Later, the equilibrium samples were immediately assayed and the partition coefficients calculated at different $\mathrm{pH}$ values.

Partition coefficients indicated the fraction of adsorbed protein at equilibrium, given by the Equation 1 (Harsa and Furusaki, 1994).

$\mathrm{f}=\frac{\mathrm{Q}^{*}}{\mathrm{~A}^{*}}$

Where $\mathrm{Q}^{*}$ and $\mathrm{A}^{*}$ were the equilibrium activity of adsorbed enzyme and free enzyme, respectively.

\section{Effect of temperature on partitioning}

This experimental was conducted using amyloglucosidase solution in $0.025 \mathrm{M}$ Tris- $\mathrm{HCl}$ buffer, $\mathrm{pH}$ 8.0. Samples were placed in shaker at different temperatures $\left(15 ; 18 ; 21\right.$ and $\left.25^{\circ} \mathrm{C}\right)$ until reaching the equilibrium, quickly assayed and the partition coefficients were calculated using Equation 1.

\section{Adsorption kinetics}

The filtrate of crude broth with $40 \mathrm{~mL}$ of amyloglucosidase solution in $0.025 \mathrm{M}$ Tris- $\mathrm{HCl}$ buffer at $\mathrm{pH} 8.0$ was mixed with $10 \mathrm{~mL}$ of wet resin (fresh prepared or recovered) in a stirred reactor at $25^{\circ} \mathrm{C}$ for $200 \mathrm{~min}$. Samples were taken from the reactor at predetermined time intervals and rapidly analyzed by enzymatic analysis and subsequent construction adsorption kinetic.

\section{Adsorption Isotherms}

Experimental data were obtained from the batch adsorption with $1 \mathrm{~mL}$ fresh prepared resin suspension in $10 \mathrm{~mL}$ of different concentrations of crude amyloglucosidase in $0.025 \mathrm{M}$ Tris- $\mathrm{HCl}$ buffer, $\mathrm{pH}$ 8.0. After two hours of incubation in the shaker $\left(25^{\circ} \mathrm{C}\right.$ and $\left.175 \mathrm{rpm}\right)$, the amount of adsorbed amyloglucosidase was determined by the analysis of the activity of the soluble phase.

\section{Calculation of $K_{d}, Q_{m}, k_{1}$ and $k_{2}$}

The kinetic equation of amyloglucosidase adsorption was expressed by Equation 2, which turned into the Langmuir model (Equation 3) at equilibrium.

$$
\begin{aligned}
& \frac{\mathrm{d} Q}{\mathrm{dt}}=\mathrm{k}_{1} \cdot \mathrm{A} \cdot\left(\mathrm{Q}_{\mathrm{m}}-\mathrm{Q}\right)-\mathrm{k}_{2} \cdot \mathrm{Q} \\
& \mathrm{Q}^{*}=\frac{\mathrm{Q}_{\mathrm{m}} \cdot \mathrm{A}^{*}}{\mathrm{~K}_{\mathrm{d}}+\mathrm{A}^{*}}
\end{aligned}
$$

Equations 2 and 3 were used to determine the kinetic parameters by means of dynamic fitting to the experimental data. The fitting procedure was performed using the fourth-order Runge-Kutta algorithm to integrate Equation 2 and the least squares procedure to optimize the fitting. In Equation 2 and $3, \quad \mathrm{Q}$ is the amount of amyloglucosidase activity adsorbed per unit volume, $\mathrm{Q}_{\mathrm{m}}$ is the maximum amount of amyloglucosidase activity adsorbed per unit volume, $\mathrm{A}$ is the amyloglucosidase activity in liquid phase, $\mathrm{k}_{1}$ and $\mathrm{k}_{2}$ are kinetics constants and $\mathrm{K}_{\mathrm{d}}$ (equal to $\mathrm{k}_{2} / \mathrm{k}_{1}$ ) is the equilibrium constant. The symbol $*$ in Equation 3 represents concentrations at the equilibrium.

\section{RESULTS AND DISCUSSION}

\section{Effect of pH on the partition coefficients}

Partition coefficients were calculated from the initial and adsorbed fraction of enzymes in ion exchange resin DEAE-cellulose.

Figure 1 showed that the partition coefficient of amyloglucosidase adsorption on resin DEAEcellulose was affected by $\mathrm{pH}$.

The minimum value for the partition coefficients was obtained at $\mathrm{pH}$ 6.5. Above this value, the partition coefficient increased and reached its peak at $\mathrm{pH}$ 8.0. Above this value, the partition coefficient decreased. Harsa and Furusaki (1994) and Cruz and Santana (1996) obtained similar curves behavior working with affinity and ion exchange resins, respectively. 


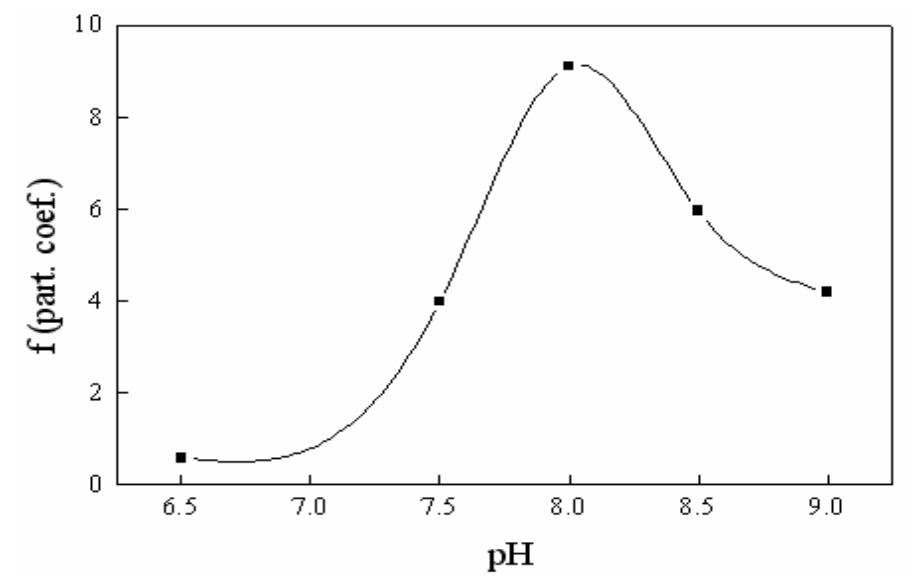

Figure 1 - Effect of $\mathrm{pH}$ on partition coefficient of amyloglucosidase on ion exchange resin DEAEcellulose with $0.025 \mathrm{M}$ Tris- $\mathrm{HCl}$ buffer.

\section{Effect of temperature on the partition} coefficients

In this study, the influence of temperature on the partition coefficient for amyloglucosidase enzymes was investigated at certain temperatures between 15 and $25^{\circ} \mathrm{C}$. Figure 2 shows the effect of temperature on partitioning.
As seen, temperature slightly affected the phase equilibria. With the decrease of the temperature, the partition coefficient decreased.

Similar situation was observed by Bautista et al. (1999), where there was an increase of about $10 \%$ in the amount $\alpha$-amylase adsorbed on the anion exchanger Duolite A-568 when the temperature was increased from 20 to $30^{\circ} \mathrm{C}$.

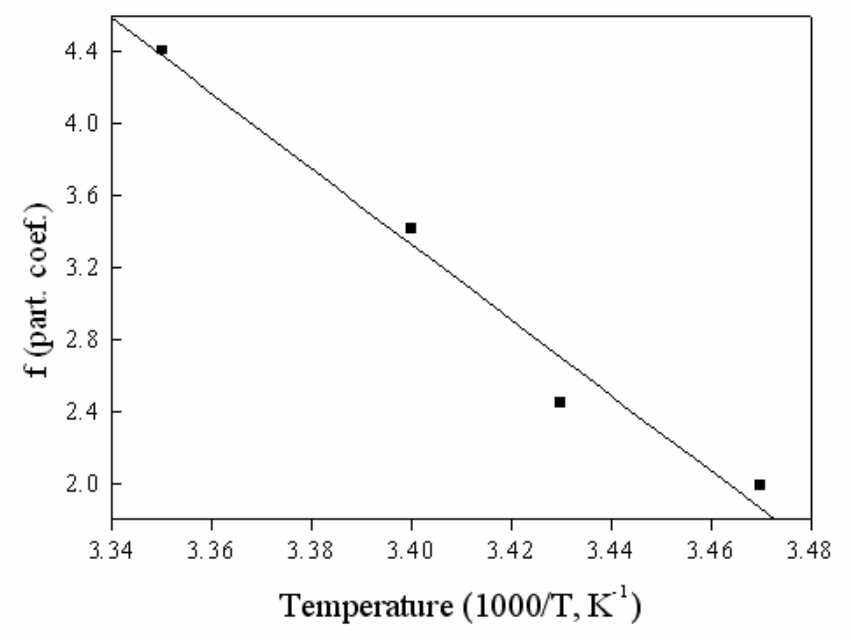

Figure 2 - Effect of temperature on partition coefficient of amyloglucosidase on ion exchange resin DEAE-cellulose with 0.025M Tris-HCl buffer $\mathrm{pH}$ 8.0. $\mathrm{R}^{2}=0.97(\mathrm{y}=-20.98 \mathrm{x}+$ 74.68).

\section{Adsorption isotherm}

The enzymatic activity of the adsorbed amyloglucosidase was measured in relation to the equilibrium concentration in the liquid phase.
The results of free enzymatic activity versus the adsorbed amount at equilibrium are shown in Figure 3 (a). The parameters were estimated from the slope and an intercept of a linearized form of 
the Langmuir expression shown in Equation 4 and Figure 3 (b).

$$
\frac{1}{\mathrm{Q}^{*}}=\frac{1}{\mathrm{Q}_{\mathrm{m}}}+\left(\frac{\mathrm{K}_{\mathrm{d}}}{\mathrm{Q}_{\mathrm{m}}}\right) \cdot\left(\frac{1}{\mathrm{~A}^{*}}\right)
$$

According to Liao et al. (2005), Langmuir equation is based on the following assumptions: the adsorption is a reversible reaction, the binding sites of the adsorbents are identical, and the target protein molecules only bind to the binding sites.

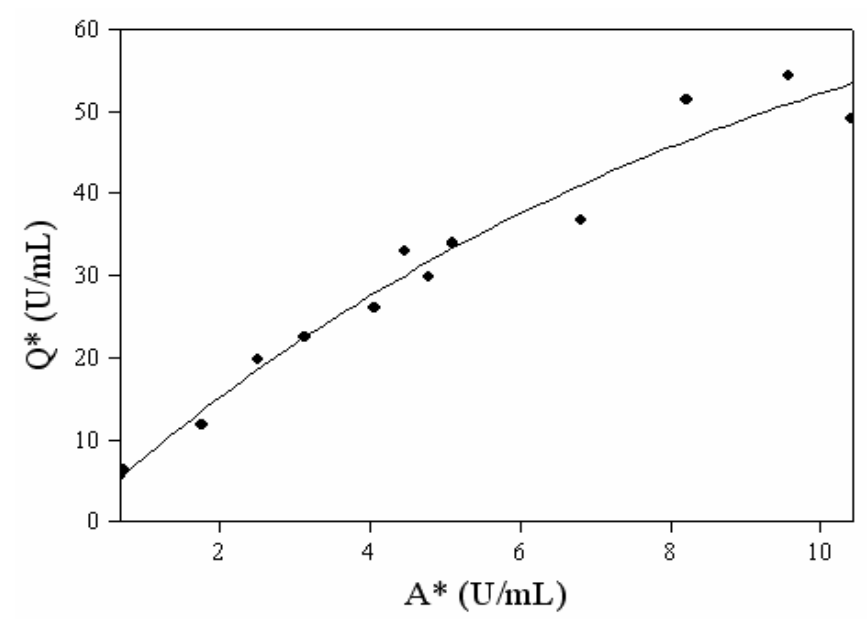

(a)

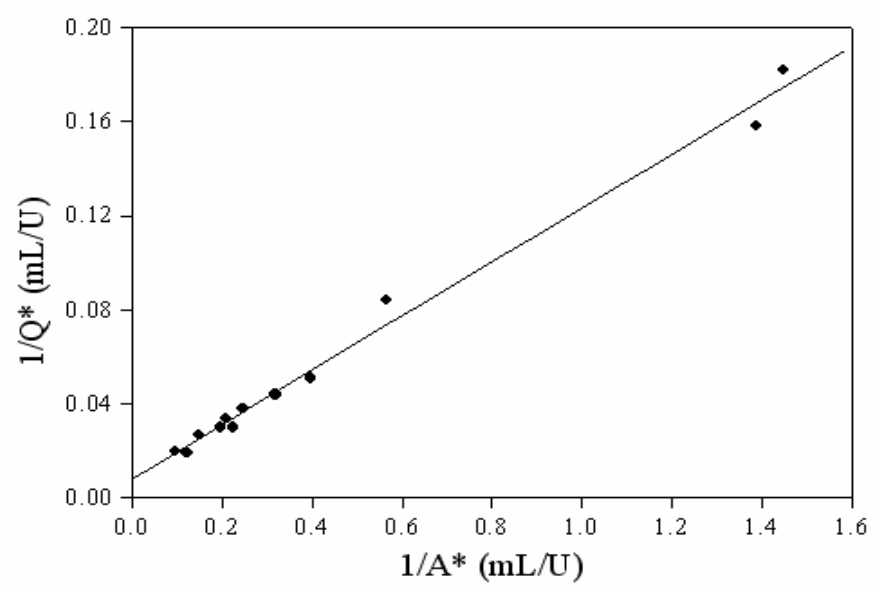

(b)

Figure 3 - Adsorption isotherm for amyloglucosidase using a fresh prepared ion exchange resin DEAE-cellulose with $0.025 \mathrm{M}$ Tris- $\mathrm{HCl}$ buffer, $\mathrm{pH} 8.0$ at $25^{\circ} \mathrm{C}$. (a) The solid line represents the fitted Langmuir equation (Equation 3). (b) Linear fitting for the determination of $\mathrm{Q}_{\mathrm{m}}$ and $\mathrm{K}_{\mathrm{d}} \cdot \mathrm{R}^{2}=0.99$.

The assumptions are valid to the isotherm as stated above since the models are actually in the same form. A Langmuir-type curve (Equation 2), fitted to these experimental data, is represented by solid line. Figure 3 (b) showed the linear fitting of the Langmuir equation to obtain values for $\mathrm{Q}_{\mathrm{m}}$ and $\mathrm{K}_{\mathrm{d}}$, which were $133.0 \mathrm{U} \mathrm{mL}^{-1}$ and $15.4 \mathrm{U} \mathrm{mL}^{-1}$, respectively. It was seen that the isotherm for amyloglucosidase adsorption could be described by the Langmuir equation with good adjustment. Pessoa Jr. et al. (1996) obtained the adsorption isotherm for inulinase from Candida kefyr on 
Streamline ${ }^{\mathrm{TM}} \mathrm{SP}$ at $\mathrm{pH} 4.0$ with $\mathrm{Q}_{\mathrm{m}}$ of $5.3 \times 10^{-6} \mathrm{U}$ $\mathrm{g}^{-1}$ and $\mathrm{K}_{\mathrm{d}}$ of $14.0 \times 10^{-8} \mathrm{U} \mathrm{mL}^{-1}$.

Barboza et al. (2002) studying clavulanic acid adsorption on anion exchanger Amberlite IRA 400 observed that the equilibrium was also obtained for Langmuir isotherm with $\mathrm{Q}_{\mathrm{m}} 2.28 \times 10^{-2} \mathrm{~g} \mathrm{~g}^{-1}, \mathrm{~K}_{\mathrm{d}}$ $3.94 \times 10^{-2} \mathrm{~g} \mathrm{~L}^{-1}, \mathrm{k}_{1} 1.11 \mathrm{~L} \mathrm{~g}^{-1} \mathrm{~min}^{-1}$ and $\mathrm{k}_{2} 0.04$ $\min ^{-1}$.

\section{Adsorption kinetics}

Figure 4 shows the adsorption of amyloglucosidase on the ion exchange resin DEAE-cellulose. Practically more than $90 \%$ of the total adsorbed enzyme was adsorbed during the first $60 \mathrm{~min}$ of reaction. This mean that there was high adsorption between the enzyme and the resin and this behavior was useful for purification process design.

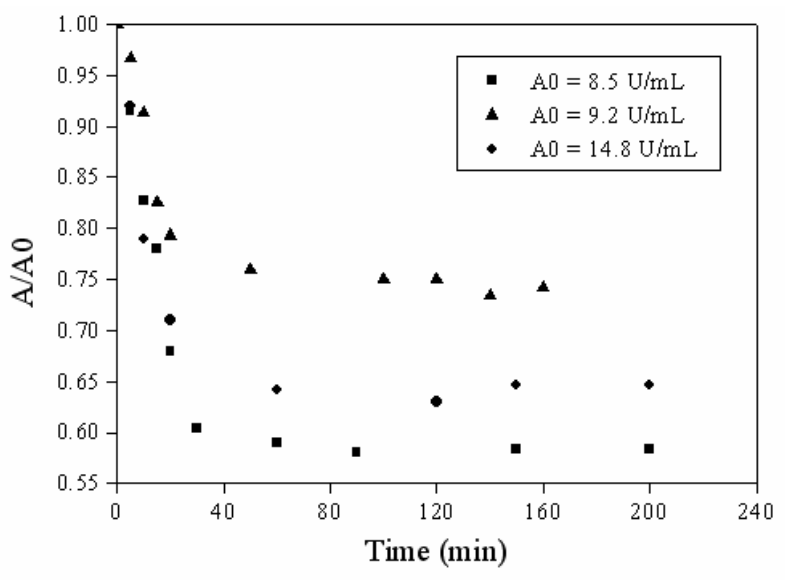

Figure 4 - Adsorption kinetics of amyloglucosidase on ion exchange resin DEAE-cellulose at $25^{\circ} \mathrm{C}$, in different initial activity of enzyme: ( $) \mathrm{A} 0=8.5 \mathrm{U} \mathrm{mL}^{-1}$ (fresh resin); ( $\boldsymbol{(}$ ) $\mathrm{A} 0=9.2 \mathrm{U} \mathrm{mL}^{-1}$ (recovered resin); $\bullet$ A $0=14.8 \mathrm{U} \mathrm{mL}^{-1}$ (fresh resin).

\section{Calculation of $k_{1}$ and $k_{2}$}

The fitting procedure was performed using the fourth-order Runge-Kutta algorithm to integrate the Equation (2) and the least squares method to optimize the fitting. Figure 5 (a-c) shows the dynamic fitting of Equation (2) to the experimental data in order to obtain $\mathrm{k}_{1}$ and $\mathrm{k}_{2}$ and $\mathrm{Q}_{\mathrm{m}}$ for each kinetic assay.

Table 1 shows initial amyloglucosidase activity, the efficiency value in percentage, $Q_{m}, K_{d}$ and the fitted kinetics constants $\left(\mathrm{k}_{1}\right.$ and $\left.\mathrm{k}_{2}\right)$ for all the kinetics adsorption assays.

In order to assess the adsorption behavior of glucoamylase on the ion exchange resin, efficiency of adsorption was defined by the Equation 5 .

efficiency $=\frac{(\text { amount of glucoamylase retained by resin })}{(\text { amount of total glucoamylase activity applied to resin) }} \times 100$

For all the runs, $\mathrm{k}_{1}$ and $\mathrm{k}_{2}$ were similar, $2.4 \times 10^{-3}$

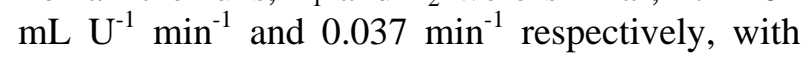
$\mathrm{Q}_{\mathrm{m}}$ changing according to fresh or recovered resin: (a) $\mathrm{Q}_{\mathrm{m}}=133.0 \mathrm{U} \mathrm{mL}^{-1}\left(\mathrm{~A} 0=8.5 \mathrm{U} \mathrm{mL}^{-1}\right.$ with fresh prepared resin); (b) $\mathrm{Q}_{\mathrm{m}}=75.0 \mathrm{U} \mathrm{mL}^{-1}(\mathrm{~A} 0=9.2 \mathrm{U}$ $\mathrm{mL}^{-1}$ with recovered resin) and (c) $\mathrm{Q}_{\mathrm{m}}=133.0 \mathrm{U}$ $\mathrm{mL}^{-1}\left(\mathrm{~A} 0=14.8 \mathrm{U} \mathrm{mL}^{-1}\right.$ with fresh prepared resin). Table 1 showed that adsorption efficiency and $\mathrm{Q}_{\mathrm{m}}$ were lower for the recovered resins, this value was adjusted (experiment $b$ with $22.5 \%$ ), than for fresh prepared resins (experiments a and c with $44.3 \%$ and $38.1 \%$, respectively).

According to adsorption isotherm carried out with fresh resins, the assays a and c presented the same $\mathrm{Q}_{\mathrm{m}}$ and $\mathrm{K}_{\mathrm{d}}$ values. It was interesting to test the recovered resin (assay b) which showed that the $\mathrm{Q}_{\mathrm{m}}$ value should be fitted to a lower value comparing with fresh resins (assay a and c).

This probably occurred because the recovered resin was used in this assay and the enzymatic extract was maintained frozen, which could denature the enzyme due to the prolonged storage. This enzyme would occupy active sites of the resin reducing the capacity of adsorption in relation to an enzyme not denatured. 


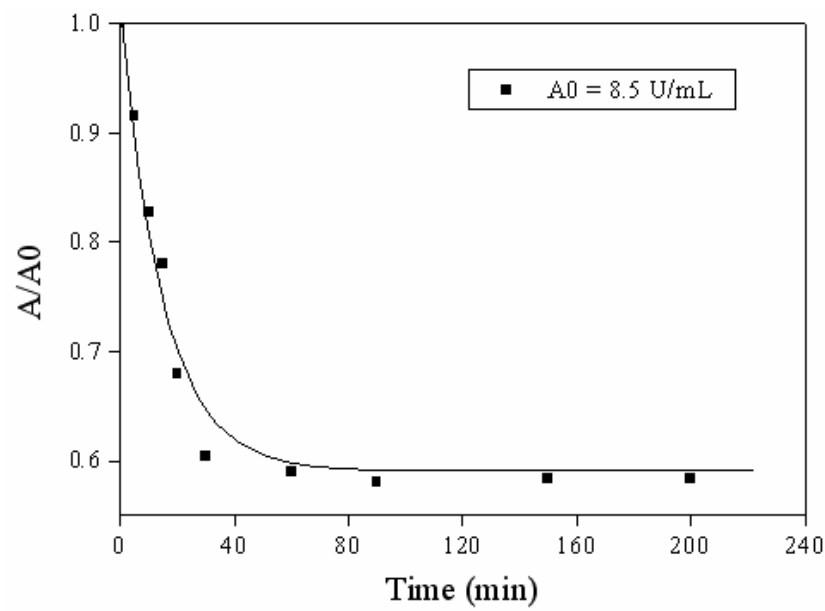

(a)

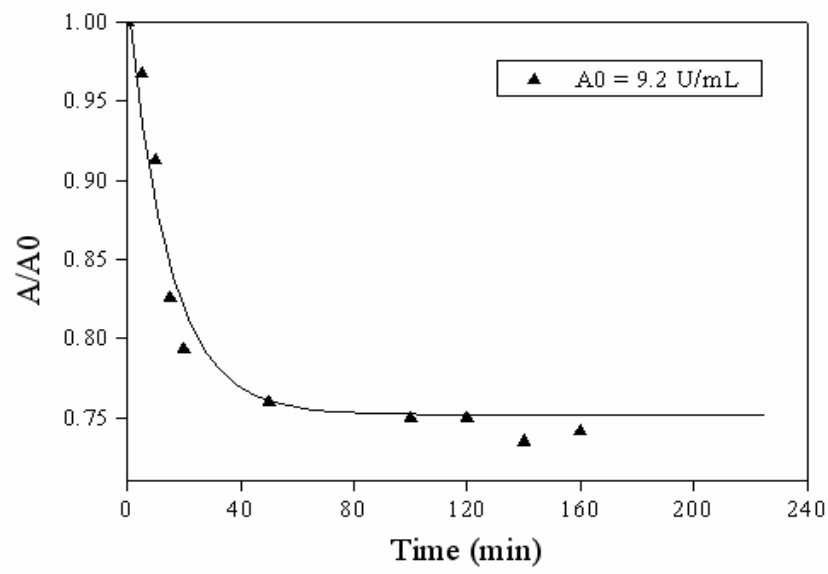

(b)

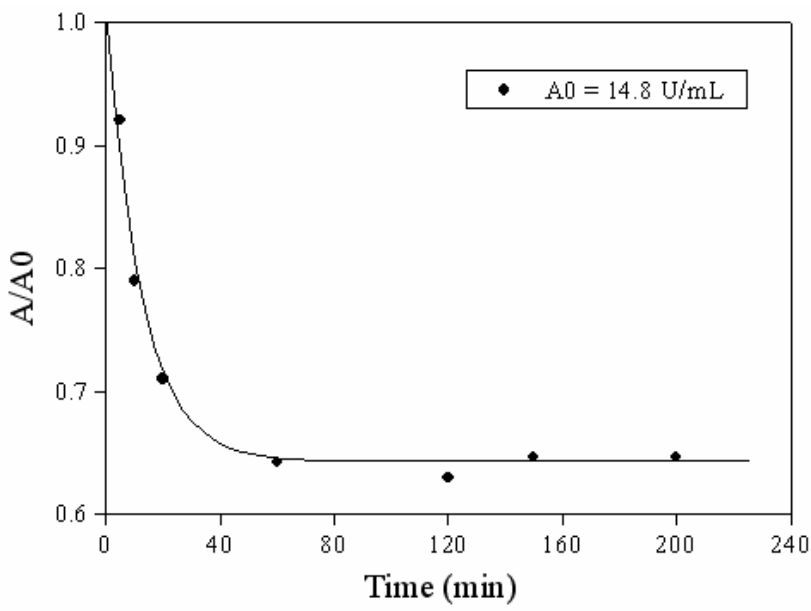

(c)

Figure 5 - Dynamic fitting of amyloglucosidase adsorption on ion exchange resin at $25^{\circ} \mathrm{C}$. Solid lines represent the predicted curve from Equation 2 and $\boldsymbol{\square}(\mathrm{a}), \boldsymbol{\bullet}(\mathrm{b}), \bullet$ (c) symbols, the experimental data. 
These problems could happen when working with crude broth instead of a system model, because the kinetic assays was made by activity analysis and not by the absorbance reading $(280 \mathrm{~nm})$, making it difficult to verify if a denatured enzyme was or wasn't adsorbed by the resin. A similar situation was observed by Kamimura et al. (1999), where the value of $\mathrm{Q}_{\mathrm{m}}$ obtained in the kinetic curves was inferior to the isotherm and when the recovered resin was used, the capacity of adsorption decreased strongly.

However, the decrease in the adsorption efficiency for the recovered resins suggested that the regeneration step should be studied carefully in order to improve it. Barboza et al. (2002) and Adriano et al. (2005) in the study of adsorption of clavulanic acid on anion exchanger resin and amoxicillin on chitosan beads, respectively, compared the simplified model for the adsorption (Equation 2) with a complete model that took in account the phenomena of internal diffusion and external convection on adsorbent, including also the mass transfer in the liquid film, the diffusion in the particle pores as well as the surface adsorption rate (model proposed by Horstman and Chase, 1989).

It was noted for both case that for smaller initial concentration the simulated curves for the simplified model and complete model were practically identical to the experimental kinetic curve. Figure 5 (a-c) showed that the simplified model (purely intrinsic model) used in this work fitted very well with the experimental data.

It was observed that $\mathrm{k}_{1}$ and $\mathrm{k}_{2}$ were essentially the same for all the runs, in contrast to $\mathrm{Q}_{\mathrm{m}}$ values, which changed according to the adsorption efficiency of the resin. Table 1 showed that $\mathrm{k}_{1}$ and $\mathrm{k}_{2}$ were $2.4 \times 10^{-3} \mathrm{~mL} \mathrm{U}^{-1} \mathrm{~min}^{-1}$ and $0.037 \mathrm{~min}^{-1}$, respectively.

Table 1 - Experimental results for amyloglucosidase adsorption efficiency (\%) and the fitted values for $\mathrm{Q}_{\mathrm{m}}, \mathrm{K}_{\mathrm{d}}, \mathrm{k}_{1}$ and $\mathrm{k}_{2}$.

\begin{tabular}{cccccccc}
\hline $\begin{array}{c}\text { Kinetic } \\
\text { assay }\end{array}$ & Resin & $\begin{array}{c}\mathbf{A 0} \\
\left(\mathbf{U} \mathbf{~ m L}^{-\mathbf{1}}\right)\end{array}$ & $\begin{array}{c}\text { Adsorption } \\
\text { efficiency } \\
(\boldsymbol{\%})\end{array}$ & $\begin{array}{c}\mathbf{Q}_{\mathbf{m}} \\
\left(\mathbf{U} \mathbf{~ m L}^{-\mathbf{1}}\right)\end{array}$ & $\begin{array}{c}\mathbf{K}_{\mathbf{d}} \\
\left(\mathbf{U} \mathbf{~ m L}^{-\mathbf{1}}\right)\end{array}$ & $\begin{array}{c}\mathbf{k}_{\mathbf{1}} \\
\left(\mathbf{m L} \mathbf{U}^{-\mathbf{1}} \mathbf{m i n}^{-\mathbf{1}}\right)\end{array}$ & $\begin{array}{c}\mathbf{k}_{\mathbf{2}} \\
\left(\mathbf{m i n}^{-\mathbf{1}}\right)\end{array}$ \\
\hline $\mathbf{a}$ & fresh & 8.5 & 44.3 & 133.0 & 15.4 & $2.4 \times 10^{-3}$ & 0.037 \\
$\mathbf{b}$ & recovered & 9.2 & 22.5 & 75.0 & 15.4 & $2.4 \times 10^{-3}$ & 0.037 \\
$\mathbf{c}$ & fresh & 14.8 & 38.1 & 133.0 & 15.4 & $2.4 \times 10^{-3}$ & 0.037 \\
\hline
\end{tabular}

Table 2 - Comparison of kinetic parameters of this present work with the related work reported in literature.

\begin{tabular}{|c|c|c|c|c|c|c|}
\hline Adsorbent & Protein & $\mathbf{Q}_{\mathbf{m}}$ & $\mathbf{K}_{\mathbf{d}}$ & $\mathbf{k}_{1}$ & $\mathbf{k}_{2}$ & Reference \\
\hline $\begin{array}{l}\text { DEAE- } \\
\text { cellulose }\end{array}$ & $\begin{array}{l}\text { Amyloglucosidase } \\
\text { Aspergillus niger }\end{array}$ & $133.0 \mathrm{U} \mathrm{mL}^{-1}$ & $\begin{array}{c}15.4 \\
\mathrm{U} \mathrm{mL}^{-1}\end{array}$ & $\begin{array}{c}2.4 \times 10^{-3} * \\
\mathrm{~mL} \mathrm{U}^{-1} \min ^{-1}\end{array}$ & $\begin{array}{l}0.037^{*} \\
\min ^{-1}\end{array}$ & This work \\
\hline $\begin{array}{c}\text { Cross-linked } \\
\beta \text {-CD-IDA- } \\
\mathrm{Cu}^{+2}\end{array}$ & $\alpha$-amylase & $39.84 \mathrm{mg} \mathrm{g}^{-1}$ & $\begin{array}{l}12.6 \times 10^{-3} \\
\mathrm{mg} \mathrm{mL}^{-1}\end{array}$ & - & - & $\begin{array}{l}\text { Liao et al., } \\
\quad 2005\end{array}$ \\
\hline $\begin{array}{c}\text { Chitosan } \\
\text { beads }\end{array}$ & Amoxicillin & $8.71 \mathrm{mg} \mathrm{g}^{-1}$ & $\begin{array}{c}0.60 \\
\mathrm{mg} \mathrm{mL}^{-1}\end{array}$ & $\begin{array}{c}\approx 0.007 \\
\mathrm{~mL} \mathrm{mg}^{-1} \mathrm{~min}^{-1}\end{array}$ & $\begin{array}{l}\approx 0.004 \\
\min ^{-1}\end{array}$ & $\begin{array}{l}\text { Adriano et al., } \\
\quad 2005\end{array}$ \\
\hline $\begin{array}{l}\text { Amberlite } \\
\text { IRA } 400 \text { anion } \\
\text { exchanger }\end{array}$ & Clavulanic acid & $2.28 \times 10^{-2} \mathrm{~g} \mathrm{~g}^{-1}$ & $\begin{array}{c}3.94 \times 10^{-2} \\
\mathrm{~g} \mathrm{~L}^{-1}\end{array}$ & $\begin{array}{c}\approx 1.11 * \\
\mathrm{Lg}^{-1} \mathrm{~min}^{-1}\end{array}$ & $\begin{aligned} \approx & 0.04 * \\
& \min ^{-1}\end{aligned}$ & $\begin{array}{l}\text { Barboza et al., } \\
\quad 2002\end{array}$ \\
\hline $\begin{array}{c}\text { EAH- } \\
\text { Sepharose 4B }\end{array}$ & $\begin{array}{c}\text { Lipase } \\
\text { Geotrichum } s p\end{array}$ & $98.90 \mathrm{U} \mathrm{g}^{-1}$ & $\begin{array}{c}2.41 \\
\mathrm{U} \mathrm{mL}^{-1}\end{array}$ & $\begin{array}{c}6 \times 10^{-2} * \\
\mathrm{~mL} \mathrm{U}^{-1} \min ^{-1}\end{array}$ & $\begin{array}{l}0.14^{*} \\
\min ^{-1}\end{array}$ & $\begin{array}{l}\text { Kamimura } \\
\text { et al., } 1999\end{array}$ \\
\hline
\end{tabular}

$\approx=$ mean, ${ }^{*}$ simplified model (Eq. 2) 
Table 2 presents some results about the comparison of the kinetic parameter of this work with others from the literature. Kamimura et al. (1999), reported adsorption and desorption kinetics constants of lipase from Geotrichum $s p$. in the resin EAH Sepharose 4B gel, as $6 \times 10^{-2} \mathrm{~mL} \mathrm{U}^{-1}$ $\min ^{-1}$ for $\mathrm{k}_{1}$ and $0.14 \min ^{-1}$ for $\mathrm{k}_{2}$. Adriano et al. (2005) studied the adsorption of amoxicillin on chitosan beds and found the values of 8.71 for $\mathrm{Q}_{\mathrm{m}}$ (mg amoxicillin $\mathrm{g}^{-1}$ wet adsorbent), 0.6 for $\mathrm{K}_{\mathrm{d}}(\mathrm{mg}$ $\left.\mathrm{mL}^{-1}\right)$, a mean of 0.007 for $\mathrm{k}_{1}\left(\mathrm{~mL} \mathrm{mg}^{-1} \mathrm{~min}^{-1}\right)$ and a mean of 0.004 for $k_{2}\left(\min ^{-1}\right)$. In this study, the concentration of amoxicillin varied from 0.236 to $2.761 \mathrm{mg} \mathrm{mL}^{-1}$ in order to get the kinetics curves. According to Adriano et al. (2005), although the simplified model was a gross simplification of the real adsorption processes, it could be useful in the system analyzed, given its simplicity and the small amount of computer required for complete model that took in account the phenomena of diffusion and mass transfer. Complete model provides more insight on the diffusion inside the particle, but it is more involved, conducting essentially to about the same fitting to their experimental data. The present work showed that the simplified model fitted well with the experimental data obtained for amyloglucosidase adsorption on ion exchange resin.

\section{CONCLUSIONS}

In this work, adsorption studies were carried out for the amyloglucosidase-resin DEAE-cellulose system. The effect of process parameters $(\mathrm{pH}$ and temperature) on the equilibrium partition coefficients was studied in order to optimize the adsorption conditions for glucoamylase enzyme. The results showed that $0.025 \mathrm{M}$ Tris- $\mathrm{HCl}$ buffer, $\mathrm{pH} 8.0$ and a temperature of $25^{\circ} \mathrm{C}$ were the optimal operating conditions.

The adsorption isotherm of amyloglucosidase measured for $\mathrm{pH} 8.0$ at $25^{\circ} \mathrm{C}$ showed a good fit to the Langmuir model. The model parameters were estimated from the linearized form of the isotherm equation and $\mathrm{Q}_{\mathrm{m}}$ and $\mathrm{K}_{\mathrm{d}}$ were $133.0 \mathrm{U} \mathrm{mL}^{-1}$ and 15.4 $\mathrm{U} \mathrm{mL}^{-1}$, respectively. The kinetic constants that were determined by the dynamic fitting using the fourth-order Runge-Kutta algorithm were $2.4 \times 10^{-3} \mathrm{~mL} \mathrm{U}^{-1} \mathrm{~min}^{-1}$ and $0.037 \mathrm{~min}^{-1}$ for $\mathrm{k}_{1}$ and $\mathrm{k}_{2}$ respectively.

\section{ACKNOWLEDGEMENTS}

Support for this research by the Fundação de Amparo à Pesquisa do Estado do Rio Grande do Sul (FAPERGS) is gratefully acknowledged.

\section{NOMENCLATURE}

f: partition coefficient

A: enzymatic activity in the liquid $\left(\mathrm{U} \mathrm{mL}^{-1}\right)$

A0: initial or inlet enzymatic activity in the liquid phase $\left(\mathrm{U} \mathrm{mL}^{-1}\right)$

$\mathrm{A}^{*}$ : $\quad$ equilibrium enzymatic activity in the liquid $\left(\mathrm{U} \mathrm{mL}^{-1}\right)$

Q: $\quad$ enzymatic in the solid phase $\left(\mathrm{U} \mathrm{mL}^{-1}\right)$

$\mathrm{Q}^{*}$ : equilibrium enzymatic activity in solid phase $\left(\mathrm{U} \mathrm{mL}^{-1}\right)$

$\mathrm{Q}_{\mathrm{m}}$ : $\quad$ Langmuir isotherm constant $\left(\mathrm{U} \mathrm{mL}^{-1}\right)$

$\mathrm{K}_{\mathrm{d}}$ : $\quad$ dissociation constant $\left(\mathrm{U} \mathrm{mL}^{-1}\right)$

$\mathrm{k}_{1}$ : adsorption kinetic constant $\left(\mathrm{mL} \mathrm{U}^{-1} \min ^{-1}\right)$

$\mathrm{k}_{2}$ : desorption kinetic constant $\left(\min ^{-1}\right)$

\section{RESUMO}

A enzima amiloglicosidase foi produzida por Aspergillus niger NRRL 3122 através de fermentação em estado sólido, tendo como substrato farelo de arroz desengordurado. Os efeitos dos parâmetros de processo $(\mathrm{pH}$ e temperatura) no coeficiente de partição no equilíbrio, para o sistema amiloglicosidase - resina DEAE-celulose foram investigados, com o objetivo de se obter as melhores condições para um posterior processo de purificação. Os maiores coeficientes de partição foram obtidos usando tampão Tris- $\mathrm{HCl} \quad 0,025 \mathrm{M} \quad \mathrm{pH} \quad 8,0$ e $25^{\circ} \mathrm{C}$. Determinadas as condições que forneceram o maior coeficiente de partição obteve-se a isoterma que melhor descrevia o processo de adsorção de amiloglicosidase. Foi verificado que adsorção pode ser bem descrita pela equação de Langmuir e os valores de $Q_{m}$ e $K_{d}$ foram estimados em 133,0 $\mathrm{U} \mathrm{mL}^{-1}$ e $15,4 \mathrm{U} \mathrm{mL}^{-1}$ respectivamente. A partir do ajuste das curvas cinéticas utilizando o método de Runge-Kutta de quarta ordem, obteve-se as constantes de adsorção $\left(\mathrm{k}_{1}\right)$ e dessorção $\left(\mathrm{k}_{2}\right)$ através da otimização pelo método dos mínimos quadrados, os valores encontrados foram $2,4 \times 10^{-3}$ $\mathrm{mL} \mathrm{U}^{-1} \min ^{-1}$ para $\mathrm{k}_{1}$ e $0,037 \min ^{-1}$ para $\mathrm{k}_{2}$. 


\section{REFERENCES}

Adriano, W. S.; Veredas, V.; Santana, C. C.; Gonçalves, L. R. B. (2005), Adsorption of amoxicillin on chitosan beads: Kinetics, equilibrium and validation of finite bath models. Biochemical Engineering Journal, 27, 132-137.

Barboza, M.; Almeida, R. M. R. G.; Hokka, C. O. (2002), Intrinsic kinetic parameters of clavulanic acid adsorption by ion-exchange chromatography. Industrial and Engineering Chemistry Research, 41, 5789-5793.

Bautista, L. F.; Martinez, M.; Aracil, J. (1999), Adsorption equilibrium of $\alpha$-amylase in aqueous solutions. AIChE Journal, 45(4), 761-768.

Chen, J.; Li, D.-C.; Zhang, Y.-Q.; Zhou, Q.-X. (2005) Purification and characterization of a thermostable glucoamylase from Chaetomium thermophilum. J. Gen. Appl. Microbiol., 51, 175-181.

Costa, J. A. V.; Alegre, R. M.; Hasan, S. D. M. (1998), Packing density and thermal conductivity determination for rice bran solid-state fermentation. Biotechnology Techniques, 12(10), 747-750.

Cruz, J. M.; Santana, C. C. (1996), Adsorção e eluição de insulina em leito fixo e fluidizado de resina trocadora de íon. In: XXIV Congresso Brasileiro de Sistemas Particulados (ENEMP), Uberlândia. Uberlândia: Editora da Universidade Federal de Uberlândia, 1997. p. 568-573.

Ellaiah, P.; Adinarayana, K.; Bhavani. Y.; Padmaja, P.; Srinivasulu, B. (2002), Optimization of process parameters for glucoamylase production under solid state fermentation by a newly isolated Aspergillus species. Process Biochemistry, 38, 615-620.

Ghildyal, N. P.; Ramakrishna, M.; Lonsane, B. K.; Karanth, N. G. (1991), Efficient and simple extraction of mouldy bran in a pulsed column extractor for recovery of amyloglucosidase in concentrated form. Process Biochemistry, 26, 235241.

Gouveia, T.; Kilikian, B. V. (2000), Bioaffinity extraction of glucoamylase in aqueous two-phase systems using starch as free bioligand. Journal of Chromatography B, 743, 241-246.

Harsa, S.; Furusaki, S. (1994), Separation of amyloglucosidase using $\beta$-cyclodextrin/chitosana. Separation Science and Technology, 29(5), 639-650.

Horstman, B. J.; Chase, H. A. (1989), Modelling the affinity adsorption of immunoglobulin $\mathrm{G}$ to protein a immobilized to agarose matrices, Chem. Eng. Res., 67(3), 243-254.
Kamimura, E. S.; Mendieta O.; Sato, H. H.; Pastore, G.; Maugeri, F. (1999), Production of lipase form Geotrichum sp and adsorption studies on affinity resin. Brazilian Journal of Chemical Engineering, 16 (2), 103-112.

Levison, P. R. (2003), Large-scale ion-exchange column chromatography of proteins: Comparison of different formats. Journal of Chromatography B, $\mathbf{7 9 0}$, 17-33.

Liao, Y.-C.; Syu, M.-J. (2005), Novel immobilized metal affinity adsorbent based on cross-linked $\beta$ cyclodextrin matrix for repeated adsorption of $\alpha$ amylase. Biochemical Engineering Journal, 23, 1724.

Marlida, Y.; Saari, N.; Hassan, Z.; Radu, S.; Bakar, J. (2000), Purification and characterization of sago starch degrading glucoamylase from Acremonium sp. endophytic fungus. Food Chemistry, 71, 221-227.

Miller, G. L. (1959), Use of dinitrosalicylic acid reagent for determination of reducing sugar. Analytical Chemistry, 31, 426-428.

Pandey, A.; Soccol, C. R.; Mitchell, D. (2000), New developments in solid state fermentation: Ibioprocesses and products. Process Biochemistry, 35(10), 1153-1169.

Pessoa Jr., A.; Hartmann, R.; Vitolo, M.; Hustedt, H. (1996), Recovery of extracellular inulinase by expanded bed adsorption. Journal of Biotechnology, 51, 89-95.

Rani, A. S.; Das, M. L. M.; Satyanarayana, S. (2000), Preparation and characterization of amyloglucosidase adsorbed on activated charcoal. Journal of Molecular Catalysis B: Enzymatic, 10(5), 471-476.

Whitaker, J. R. (1994), The Glycoside Hydrolases. InPrinciples of enzymology for the food sciences, 2ed. Marcel Dekker, New York, pp. 391-423.

Received: June 27, 2005; Revised: November 14, 2007; Accepted: June 19, 2008. 